\title{
Reviews - a journey on innovation from the past into the future
}

\author{
João José Pinto Ferreira \\ jjpf@fe.up.pt | INESC Technology and Science, Faculty of Engineering, University of Porto, Portugal \\ Anne-Laure Mention \\ anne-laure.mention@rmit.edu.au | RMIT University, Australia \\ Marko Torkkeli \\ marko.torkkeli@lut.fi | Lappeenranta University of Technology, Finland
}

\section{Editorial}

Reviews of literature including systematic meta-analysis are invaluable to advance science and guide directions for future research. The premise for conducting reviews is well established (Dickersin \& Berlin, 1992; Glass, 1976). Systematic reviews in a field gather scholarly efforts on a topic, theme, population, setting and treatment conditions to identify peculiarities and generalizations across subsets. Reviews thus increase power and precision of causal inferences and estimates of relationships between constructs and help manage literature "blind spots" by increasing reliability and validity of results from widely dispersed regional and global studies. The advantage of reviews is thus especially noticeable in cases where occurrence rates of conditions or events are particularly low or where small effect sizes equally matter (e.g. in medical research) (Lau et al., 1992). The cumulation of diverse perspectives in a review offers nuances that cannot be found from a single study. This is mostly because each study is shaped by researcher's cognitive capabilities and is influenced by the characteristics of research design including selection criteria for participants, research context including treatment conditions and sophistication of methods employed (Light \& Pillemer, 1984). A formal meta-analysis of reviews in this view is more likely to detect small but significant effects than a single review performed by a researcher using traditional methods (Rosenthal, Cooper \& Hedges, 1994).

More specifically, for innovation management a review of literature is needed to reduce large amounts of scientific conceptualization, data and interpretations into manageable segments for meaningful integration. A benefit of this exercise is that it allows for critical reflection, examination and synthesis of literature, allowing for identification of insignificant and redundant outputs from salient and noteworthy research (Morgan, 1986). Moreover, a critical task for innovation 


\section{Documents by year}

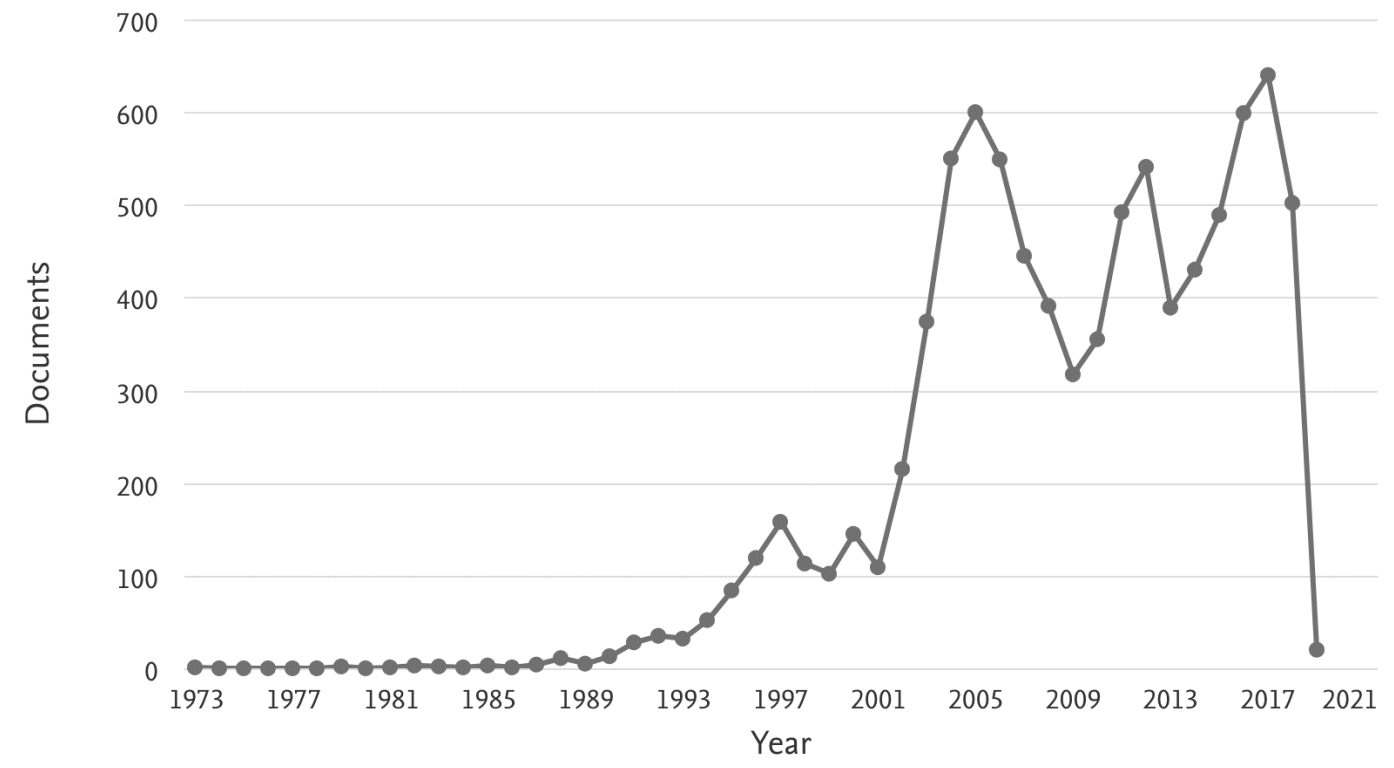

Fig. 1. Documents by year in SCOPUS using the search: KEY (innovation) AND (LIMIT-TO (DOCTYPE,"re"))

researchers is to integrate key constructs to explain the theoretical basis for phenomenon found in practice. A review can help researchers manage time and effort by avoiding paths which have already been widely explored (see Rosenbusch, Brinckmann \& Bausch, 2011). Researchers use reviews to develop propositions and hypotheses, recognise limitations of previous work, refine data collection methods including sampling approaches and delineate results that call for further research. Likewise, policy makers rely on estimates of critical integrators revealed in systematic reviews to gather thoughts, engage stakeholders and develop calls for specialised actions (Garfield, 1987; Lederberg, 1986). Last but not the least, focused reviews on questions of relevance to innovation practice and management decisions can help formulate behavioural intervention mechanisms to shape current perceptions, processes and practices towards a desired future (Cook, Possingham \& Fuller, 2012).

In this editorial we analyse how publication on innovation has evolved along time. To this end, we conducted a search on 10 January 2019 on SCOPUS database and limited to documents classified as "Reviews". The results on number of documents by subject are identified in table 1 and a graph of documents by year is depicted as figure 1. In this table is it interesting to confirm that the first four areas (Medicine, Business, Management and Accounting, Social Sciences and Engineering) cumulate to $53,9 \%$ to the total number of documents. 
Table 1. Number of documents per subject area in SCOPUS using the search: KEY (innovation) AND (LIMIT-TO (DOCTYPE, "re"))

\begin{tabular}{|c|c|}
\hline Subject area & Documents \\
\hline Medicine & 3037 \\
\hline Business, Management and Accounting & 1713 \\
\hline Social Sciences & 1562 \\
\hline Engineering & 1166 \\
\hline Nursing & 1036 \\
\hline Environmental Science & 576 \\
\hline Economics, Econometrics and Finance & 485 \\
\hline Computer Science & 451 \\
\hline Biochemistry, Genetics and Molecular Biology & 417 \\
\hline Agricultural and Biological Sciences & 392 \\
\hline Arts and Humanities & 346 \\
\hline Energy & 329 \\
\hline Chemical Engineering & 309 \\
\hline Materials Science & 295 \\
\hline Health Professions & 241 \\
\hline Pharmacology, Toxicology and Pharmaceutics & 236 \\
\hline Decision Sciences & 193 \\
\hline Chemistry & 170 \\
\hline Earth and Planetary Sciences & 140 \\
\hline Psychology & 137 \\
\hline Physics and Astronomy & 111 \\
\hline Multidisciplinary & 106 \\
\hline Immunology and Microbiology & 87 \\
\hline Mathematics & 68 \\
\hline Neuroscience & 48 \\
\hline Dentistry & 34 \\
\hline Veterinary & 24 \\
\hline Undefined & 158 \\
\hline Total & 13867 \\
\hline
\end{tabular}

In face of the overwhelming number of documents, this first analysis was followed by the extraction to Microsoft Excel ${ }^{T M}$ worksheet of only the records in the SCOPUS database since 2008 using the successive search terms:

KEY (innovation) AND PUBYEAR AFT 2015 AND (LIMIT-TO (DOCTYPE, "re")) 
KEY (innovation) AND (PUBYEAR AFT 2011 AND PUBYEAR BEF 2016) AND (LIMIT-TO (DOCTYPE, "re"))

KEY (innovation) AND (PUBYEAR AFT 2007 AND PUBYEAR BEF 2012) AND (LIMIT-TO (DOCTYPE, "re"))

The result of this search was a list with 5166 papers.

From these papers and for the sake of this analysis we removed the Reviews with PubMed ${ }^{1}$ ID's. This ensured the removal of most of the papers associated with life sciences and biomedical topics. 2067 papers were removed. The decision to remove these papers was mainly motivated from the authors' lack of familiarity with the topics in those areas of knowledge. We were then left with the total of 3099 papers. These papers were ordered by "Source Title" bringing to the top the publications with the higher number of papers. Table 2. shows the Source Titles that represent less than $26 \%$ of those 3099 papers.

Table 2. Journals representing less than $26 \%$ of the total number of Reviews (the H Index was extracted from the Scimago Journal Rank ${ }^{2}$ ).

\begin{tabular}{lccc}
\hline Source Title & \#Papers & $\%$ & H index \\
\hline Strategic Direction & 178 & $5,77 \%$ & Q4 \\
Renewable and Sustainable Energy Reviews & 93 & $8,78 \%$ & Q1 \\
Research Technology Management & 51 & $10,44 \%$ & Q1 \\
Current Opinion in Environmental Sustainability & 39 & $11,70 \%$ & Q1 \\
Journal of Cleaner Production & 34 & $12,80 \%$ & Q1 \\
International Journal of Innovation Management & 32 & $13,84 \%$ & Q2 \\
Sustainability & 22 & $14,55 \%$ & Q2 \\
Journal of Product Innovation Management & 20 & $15,20 \%$ & Q1 \\
Revue d'Economie Industrielle & 19 & $15,82 \%$ & Q4 \\
Journal of Commercial Biotechnology & 18 & $16,40 \%$ & Q4 \\
Design Principles and Practices & 16 & $16,92 \%$ & Q3 \\
International Journal of Innovation and Learning & 15 & $17,41 \%$ & Q3 \\
Strategic Management Journal & 15 & $17,89 \%$ & Q1 \\
Trends in Food Science and Technology & 15 & $18,38 \%$ & Q1 \\
Agronomy for Sustainable Development & 14 & $18,83 \%$ & Q1 \\
Energy and Environmental Science & 14 & $19,29 \%$ & Q1 \\
NTT Technical Review & 14 & $19,29 \%$ & Q3 \\
International Journal of Technology Management & 13 & $19,71 \%$ & Q2 \\
International Journal of Innovation Science(s?) & 12 & $20,10 \%$ & Q3 \\
European Journal of Innovation Management & 11 & $20,45 \%$ & Q2 \\
Applied Energy & 10 & $20,78 \%$ & Q1 \\
PubMd a fre sar eng & & &
\end{tabular}

$1 \quad$ PubMed is a free search engine accessing primarily the MEDLINE database of references and abstracts on life sciences and biomedical topics.

2 ttps://www.scimagojr.com/ 


\begin{tabular}{lccc}
\hline Source Title & \#Papers & $\%$ & H index \\
\hline California Management Review & 10 & $21,10 \%$ & Q1 \\
Science & 10 & $21,43 \%$ & Q1 \\
Technovation & 10 & $21,75 \%$ & Q1 \\
Communications of the ACM & 9 & $22,04 \%$ & Q1 \\
Industrial Robot & 9 & $22,33 \%$ & Q2 \\
Innovation: Management, Policy and Practice & 9 & $22,63 \%$ & Q3 \\
Journal of Management & 9 & $22,92 \%$ & Q1 \\
Journal of Management Development & 9 & $23,21 \%$ & Q1 \\
MIS Quarterly: Management Information Systems & 9 & $23,50 \%$ & Q1 \\
Sea Technology & 9 & $23,79 \%$ & Q4 \\
Sociologia del Lavoro & 9 & $24,08 \%$ & Q3 \\
International Journal of Business Innovation and Research & 8 & $24,34 \%$ & Q2 \\
International Journal of Innovation and Technology Management & 8 & $24,60 \%$ & Q4 \\
Journal of Knowledge Management & 8 & $24,86 \%$ & Q1 \\
Journal of Technology Management and Innovation & 8 & $25,12 \%$ & Q3 \\
Worldwide Hospitality and Tourism Themes & 8 & $25,38 \%$ & Q3 \\
Advanced Engineering Materials & 7 & $25,61 \%$ & Q1 \\
Development and Learning in Organisations & 7 & $25,83 \%$ & Q4 \\
\hline
\end{tabular}

The journals listed in Table 1 are responsible for publishing 25,83\% of all papers in the database. With this list, we went through a final document filtering, extracting from the database all documents published in the above journals.

Further, to make the analysis of keywords feasible:

- Papers with no "Author Keywords" or "Index Keywords" were excluded

- The "Author Keywords" or "Index Keywords" were concatenated, thus leading to the possible duplication of some keywords. These duplicates were not removed as: 1) only very few keywords are in fact duplicated and 2) some papers have don't even have duplicated keywords.

The overwhelming number of keywords led to the need to restrict this keyword analysis. Finally, the search was limited to the last two years, 2017, 2018 and the few papers already available for 2019. This resulted in 195 papers published in the Journals listed in table 3, representing the total of 2286 keyword occurrences.

Table 3. Journals whose selected papers were the target of the keyword analysis.

\begin{tabular}{lc}
\hline Journal & Number of Papers \\
\hline Strategic Direction & 56 \\
Renewable and Sustainable Energy Reviews & 38 \\
Journal of Cleaner Production & 24
\end{tabular}




\begin{tabular}{lc}
\hline Journal & Number of Papers \\
\hline Current Opinion in Environmental Sustainability & 12 \\
Sociologia del Lavoro & 9 \\
Trends in Food Science and Technology & 7 \\
International Journal of Innovation Management & 6 \\
Sea Technology & 6 \\
International Journal of Innovation Science & 4 \\
European Journal of Innovation Management & 3 \\
JOM & 3 \\
Journal of Commercial Biotechnology & 3 \\
Journal of Management Development & 3 \\
Journal of Technology Management and Innovation & 3 \\
Revue d'Economie Industrielle & 3 \\
Agronomy for Sustainable Development & 2 \\
Applied Energy & 2 \\
International Journal of Innovation and Technology Management & 2 \\
International Journal of Technology Management & 2 \\
Industrial Robot & 1 \\
Innovation: Management, Policy and Practice & 1 \\
International Journal of Innovation and Learning & 1 \\
Journal of Knowledge Management & 1 \\
MIS Quarterly: Management Information Systems & 1 \\
Science & 1 \\
Technovation & 1 \\
\hline
\end{tabular}

Table 4 presents $25 \%$ of the keyword counting in the 195 papers. A brief analysis of this table reveals that $34 \%$ of these keywords $(24 / 71)$ relate to the topic of:

1. Energy:

energy; energy intensity; energy policy; energy utilization; biodiesel; fossil fuels; gas emissions; low-carbon technologies; renewable energies; renewable energy; renewable energy resources; renewable energy technologies; solar;

2. Climate change, Environmental issues and sustainability:

climate change; eco-innovation; ecosystems; environmental impact; environmental management; environmental performance; environmental protection; greenhouse gases; sustainability; sustainable development; sustainable innovation. 
Table 4. Occurrences of 71 Keywords representing $25 \%$ of the total occurring in the 195 papers

\begin{tabular}{|c|c|c|}
\hline Keyword & Occurrences & Accumulated $\%$ \\
\hline innovation & 100 & $4 \%$ \\
\hline sustainable development & 32 & $6 \%$ \\
\hline open innovation & 19 & $7 \%$ \\
\hline sustainability & 19 & $7 \%$ \\
\hline commerce & 14 & $8 \%$ \\
\hline technological innovation & 14 & $9 \%$ \\
\hline business model innovation & 12 & $9 \%$ \\
\hline eco-innovation & 12 & $10 \%$ \\
\hline competition & 11 & $10 \%$ \\
\hline energy policy & 10 & $11 \%$ \\
\hline renewable energy resources & 10 & $11 \%$ \\
\hline literature review & 9 & $11 \%$ \\
\hline strategy & 9 & $12 \%$ \\
\hline systematic literature review & 9 & $12 \%$ \\
\hline developing countries & 8 & $13 \%$ \\
\hline diffusion & 8 & $13 \%$ \\
\hline biodiesel & 7 & $13 \%$ \\
\hline energy utilization & 7 & $14 \%$ \\
\hline environmental management & 7 & $14 \%$ \\
\hline investments & 7 & $14 \%$ \\
\hline literature reviews & 7 & $14 \%$ \\
\hline product innovation & 7 & $15 \%$ \\
\hline public policy & 7 & $15 \%$ \\
\hline renewable energies & 7 & $15 \%$ \\
\hline technological development & 7 & $16 \%$ \\
\hline absorptive capacity & 6 & $16 \%$ \\
\hline barriers & 6 & $16 \%$ \\
\hline business model & 6 & $16 \%$ \\
\hline climate change & 6 & $17 \%$ \\
\hline collaboration & 6 & $17 \%$ \\
\hline economics & 6 & $17 \%$ \\
\hline entrepreneurship & 6 & $18 \%$ \\
\hline fossil fuels & 6 & $18 \%$ \\
\hline innovation system & 6 & $18 \%$ \\
\hline renewable energy & 6 & $18 \%$ \\
\hline review & 6 & $19 \%$ \\
\hline decision making & 5 & $19 \%$ \\
\hline economic and social effects & 5 & $19 \%$ \\
\hline
\end{tabular}




\begin{tabular}{|c|c|c|}
\hline Keyword & Occurrences & Accumulated \% \\
\hline ecosystems & 5 & $19 \%$ \\
\hline environmental impact & 5 & $19 \%$ \\
\hline gas emissions & 5 & $20 \%$ \\
\hline greenhouse gases & 5 & $20 \%$ \\
\hline product design & 5 & $20 \%$ \\
\hline renewable energy technologies & 5 & $20 \%$ \\
\hline sustainable innovation & 5 & $21 \%$ \\
\hline systematic review & 5 & $21 \%$ \\
\hline artificial intelligence & 4 & $21 \%$ \\
\hline big data & 4 & $21 \%$ \\
\hline brazil & 4 & $21 \%$ \\
\hline china & 4 & $21 \%$ \\
\hline commercialization & 4 & $22 \%$ \\
\hline competitive advantage & 4 & $22 \%$ \\
\hline construction industry & 4 & $22 \%$ \\
\hline energy & 4 & $22 \%$ \\
\hline energy intensity & 4 & $22 \%$ \\
\hline engineering education & 4 & $23 \%$ \\
\hline engineering research & 4 & $23 \%$ \\
\hline environmental performance & 4 & $23 \%$ \\
\hline environmental protection & 4 & $23 \%$ \\
\hline human & 4 & $23 \%$ \\
\hline industrial engineering & 4 & $23 \%$ \\
\hline life cycle & 4 & $24 \%$ \\
\hline low-carbon technologies & 4 & $24 \%$ \\
\hline networks & 4 & $24 \%$ \\
\hline patents and inventions & 4 & $24 \%$ \\
\hline planning & 4 & $24 \%$ \\
\hline production engineering & 4 & $24 \%$ \\
\hline research and development & 4 & $25 \%$ \\
\hline research work & 4 & $25 \%$ \\
\hline responsibility & 4 & $25 \%$ \\
\hline solar & 4 & $25 \%$ \\
\hline
\end{tabular}

Still under these topics, a non-exhaustive sample of the remaining keywords along these areas, is listed in following bullet points:

- alternative energy source; alternative to fossil fuels; biodiesel production; bioethanol; biofuel; biofuels; biogas; biogas technologies; biomass; bionic building energy efficiency; building energy efficiency; cellulosic ethanol; clean energy systems; clean energy technology; clean technologies 
- carbon; carbon accounting; carbon emission; carbon emissions reductions; CO2 emissions; decarbonization; low carbon

- ecosystem; coastal water; coastal zone; coastal zone management; effluent treatment

- cooking energies; cooking energy; distributed energy; distributed energy resources; distributed renewable energy generations; domestic biogas; drivers of eco-innovation; eco-friendly dyeing; eco-friendly; eco-innovation in corporate environment; eco-innovation model; ecodesign; ecological approach; ecological economics

- electricity market; electricity sector; power markets; regulatory frameworks

- energy budget; energy conservation; energy consumption; energy efficiency; energy generations; energy innovation; energy intensive material; energy market; energy markets; energy production; energy productions; energy research; energy research and social science; energy resources; energy services; energy storage; energy technologies; energy use; energy use efficiency

- environment; environmental analysis; environmental benefits; environmental challenges; environmental dimensions; environmental economics; environmental improvements; environmental innovation; environmental innovations; environmental innovativeness; environmental issues; environmental kuznets curves; environmental legislations; environmental management systems; environmental monitoring; environmental planning; environmental policy; environmental pollutions; environmental restoration; environmental strategy; environmental sustainability; environmental taxation; environmental technology

- gases; global climate changes; global sustainability; global warming; global warming and climate changes; greenhouse effect; greenhouse gas emissions; lignocellulosic biomass

- green absorptive capacity; green adaptive capacity; green clusters; green economy; green energy; green innovation; green innovation performance; green jobs; green policies; green supply chain; green supply chain management; green technology

- enhanced oil recovery; ethanol; fossil fuel; fuel ethanol; fuels; gas industry; oil and gas industry

- offshore wind; offshore winds; photovoltaic; photovoltaic cells; photovoltaic technology; renewable electricity; renewable energy consumption; renewable penetration; renewable resource; renewable sources; solar energy; solar garden; solar photovoltaic (pv); solar photovoltaics; solar power generation

- sustainable packaging; sustainable resources; sustainable society; sustainability transition; triple bottom line

We acknowledge that hours of work spent in developing, conducting and interpreting a study, ultimately, is only a part of the much larger puzzle. In this editorial we aimed to identify the intricacies and peculiarities of reviews conducted in various fields. Our results identify the diverse and widely distributed nature of innovation research. From the various tables, subsets of how innovation research has proliferated academic research can be gleaned.

\section{This study has obvious limitations}

For the sake of feasibility, there was a need to remove some contributions and, in this context, exclude some relevant journals and papers, and consequently, exclude relevant keywords. Out of curiosity, in the annex one may find a table with the list of the first most used 100 "Author 
keywords" out of 21159 keywords extracted from full database of 5166 papers. Overall, the first 20 most used keywords are:

1. innovation $(5,9 \%)$

2. open innovation $(0,45 \%)$

3. innovations $(0,42 \%)$

4. technology $(0,39 \%)$

5. sustainability $(0,34 \%)$

6. creativity $(0,3 \%)$

7. research $(0,26 \%)$

8. leadership $(0,26 \%)$

9. technological innovation $(0,26 \%)$

10. education $(0,25 \%)$

11. entrepreneurship $(0,23 \%)$

12. china $(0,23 \%)$

13. diffusion of innovation $(0,22 \%)$

14. implementation $(0,21 \%)$

15. literature review $(0,21 \%)$

16. social innovation $(0,2 \%)$

17. review $(0,18 \%)$

18. knowledge management $(0,18 \%)$

19. systematic review $(0,18 \%)$

20. strategy $(0,17 \%)$

Energy and Renewable energy discussed before, appear respectively in the 45th and 94th place, whereas sustainability emerges in the 5 th place.

A search for Review papers in Journal of Innovation Management (JIM) would produce 6 papers, listed in table 4 and gives an idea of the topics that have been handled in the JIM Reviews.

Table 4. Reviews published in the Journal of Innovation Management

\begin{tabular}{lcl}
\hline Paper Title & Vol(issue) & Keywords \\
\hline $\begin{array}{l}\text { Trends in mobile payments research: } \\
\text { A literature review }\end{array}$ & $3(1)$ & $\begin{array}{l}\text { Literature Review, Mobile Payments, } \\
\text { m-Payments. }\end{array}$ \\
$\begin{array}{l}\text { Open Innovation research: trends and } \\
\text { influences - a bibliometric analysis }\end{array}$ & $3(2)$ & $\begin{array}{l}\text { Innovation, Open Innovation, Research Trends, } \\
\text { Research Areas, Open Innovation Impact, }\end{array}$ \\
& & $\begin{array}{l}\text { Bibliometric Analysis, Theoretical Review, } \\
\text { Theoretical Influence, Influential Authors, }\end{array}$ \\
& & $\begin{array}{l}\text { Time Periods, Longitudinal Analysis. } \\
\text { Antecedents of organizational }\end{array}$ \\
creativity: drivers, barriers or both? & $5(1)$ & $\begin{array}{l}\text { Organizational creativity; Organization } \\
\text { Studies; Creativity; Literature review }\end{array}$ \\
$\begin{array}{l}\text { Front End of Innovation: An } \\
\text { Integrative Literature Review }\end{array}$ & $5(1)$ & $\begin{array}{l}\text { Innovation; Front-End of Innovation; FEI; } \\
\text { Integrative Literature Review }\end{array}$
\end{tabular}




\begin{tabular}{lcl}
\hline Paper Title & Vol(issue) & Keywords \\
\hline $\begin{array}{l}\text { User-driven innovation and } \\
\text { technology-use in public health and }\end{array}$ & $6(2)$ & $\begin{array}{l}\text { Innovation, Technology, Welfare Services, } \\
\text { Systematic Review }\end{array}$ \\
$\begin{array}{l}\text { social care: A systematic review of } \\
\text { existing evidence }\end{array}$ & & \\
$\begin{array}{l}\text { Mobile payments: A proposal for a } \\
\text { context-oriented approach based on } \\
\text { socio-technical theory }\end{array}$ & $6(3)$ & $\begin{array}{l}\text { Literature review; Mobile payments; } \\
\text { m-Payments; Socio-technical systems }\end{array}$ \\
\hline
\end{tabular}

Advantages of reviews are many, and one of them is that reviews are most likely to be cited.

For JIM, we welcome reviews, addressing the multidisciplinary nature of the innovation perceptions, processes and practices, combining principles and concepts originating from a myriad of scientific areas, from social sciences to technology research and development.

As we aim at covering a wide range of topics, from economics and social science areas to technology and science and product innovation management, new Editors are being added to our Board whenever we need a new area of competence to cover a new specific topic submitted to this Journal. Your contribution is therefore most welcome.

Innovatively yours, João José Pinto Ferreira, Anne-Laure Mention, Marko Torkkeli The Editors

\section{References}

Cook, C.N., Possingham, H.P. and Fuller, R.A., 2013. Contribution of systematic reviews to management decisions. Conservation Biology, 27(5), pp.902-915.

Dickersin, K. and Berlin, J.A., 1992. Meta-analysis: state-of-the-science. Epidemiologic reviews, 14(1), pp.154-176.

Garfield, E., 1987. Reviewing review literature 2: The place of reviews in the scientific literature. Current Contents, 19, pp.3-8.

Glass, G.V., 1976. Primary, secondary, and meta-analysis of research. Educational researcher, 5(10), pp.3-8.

Lau, J., Antman, E.M., Jimenez-Silva, J., Kupelnick, B., Mosteller, F. and Chalmers, T.C., 1992. Cumulative meta-analysis of therapeutic trials for myocardial infarction. New England Journal of Medicine, 327(4), pp.248-254.

Lederberg, J., 1989. Biomedical science and the Third World. Under the volcano. Introduction. Annals of the New York Academy of Sciences, 569, pp.19-20.

Light, R. and Pillemer, D.B., 1984. Summing up. Cambridge, MA: Harvard University Press.

Morgan, P.P., 1986. Review articles: 2. The literature jungle. Canadian Medical Association Journal, 134(2), p.98. 
Rosenbusch, N., Brinckmann, J. and Bausch, A., 2011. Is innovation always beneficial? A metaanalysis of the relationship between innovation and performance in SMEs. Journal of Business Venturing, 26(4), pp.441-457.

Rosenthal, R., Cooper, H. and Hedges, L.V., 1994. Parametric measures of effect size. The handbook of research synthesis, 621, pp.231-244. 


\section{Annex}

Table A.1. List of the first most used 100 "Author keywords" out of 21159 keywords extracted from 5166 papers. "Index Keywords" were not used in this listing.

\author{
1. innovation $(5,9 \%)$ \\ 2. open innovation $(0,45 \%)$ \\ 3. innovations $(0,42 \%)$ \\ 4. technology $(0,39 \%)$ \\ 5. sustainability $(0,34 \%)$ \\ 6. creativity $(0,3 \%)$ \\ 7. research $(0,26 \%)$ \\ 8. leadership $(0,26 \%)$ \\ 9. technological innovation $(0,26 \%)$ \\ 10. education $(0,25 \%)$ \\ 11. entrepreneurship $(0,23 \%)$ \\ 12. china $(0,23 \%)$ \\ 13. diffusion of innovation $(0,22 \%)$ \\ 14. implementation $(0,21 \%)$ \\ 15. literature review $(0,21 \%)$ \\ 16. social innovation $(0,2 \%)$ \\ 17. review $(0,18 \%)$ \\ 18. knowledge management $(0,18 \%)$ \\ 19. systematic review $(0,18 \%)$ \\ 20. strategy $(0,17 \%)$ \\ 21. collaboration $(0,17 \%)$ \\ 22. organizational innovation $(0,17 \%)$ \\ 23. learning $(0,17 \%)$ \\ 24. management $(0,17 \%)$ \\ 25 . sustainable development $(0,16 \%)$ \\ 26. research and development $(0,16 \%)$ \\ 27. ethics $(0,16 \%)$ \\ 28. quality improvement $(0,15 \%)$ \\ 29. patents $(0,15 \%)$ \\ 30. policy $(0,15 \%)$ \\ 31. history $(0,15 \%)$ \\ 32. technology transfer $(0,15 \%)$ \\ 33. innovation management $(0,15 \%)$ \\ 34. evidence-based practice $(0,15 \%)$ \\ 35 . product innovation $(0,14 \%)$ \\ 36. diffusion $(0,13 \%)$ \\ 37. organizational change $(0,12 \%)$ \\ 38 . intellectual property $(0,12 \%)$ \\ 39. educational innovation $(0,12 \%)$ \\ 40. new product development $(0,11 \%)$ \\ 41. governance $(0,11 \%)$ \\ 42. climate change $(0,11 \%)$ \\ 43. business model innovation $(0,11 \%)$ \\ 44. $r \& d(0,11 \%)$ \\ 45. renewable energy $(0,1 \%)$ \\ 46. nursing $(0,1 \%)$ \\ 47. information technology $(0,1 \%)$ \\ 48. india $(0,1 \%)$ \\ 49. development $(0,1 \%)$ \\ 50. disruptive innovation $(0,1 \%)$
}

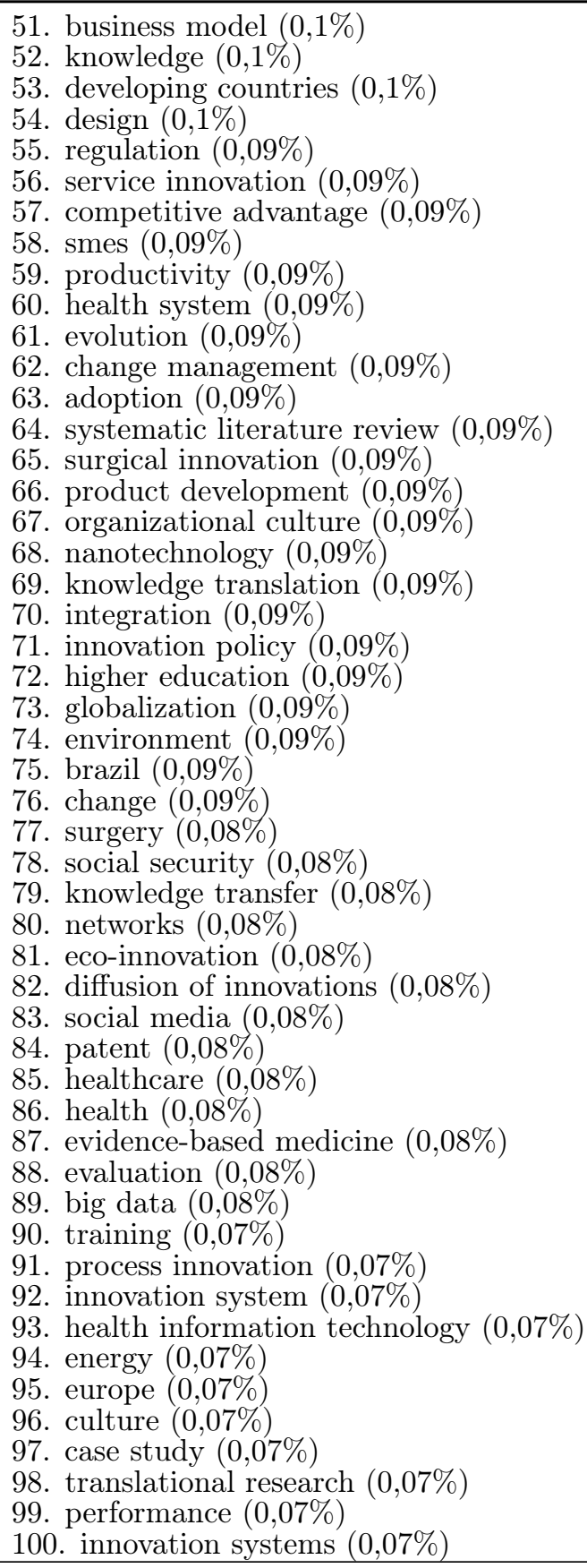


Cite paper as: Pinto Ferreira, J.J., Mention, A., Torkkeli , M., (2018). Reviews - a journey on innovation from the past into the future - Editorial, Journal of Innovation Management, www.open-jim.org, 6(4), 1-14. http://hdl.handle.net/10216/118596; DOI: https://doi.org/10.24840/2183-0606_006.004_0001 